\title{
Rancang Bangun Antena Mikrostrip Patch Serangga untuk Aplikasi Monitoring Komposter pada Frekuensi $2,4 \mathrm{GHz}$
}

\author{
Muhammad Faris ${ }^{1}$, Shita Fitria Nurjihan ${ }^{2}$ \\ Program Studi Telekomunikasi, Jurusan Teknik Elektro, Politeknik Negeri Jakarta \\ Jl. Prof. Dr. G.A. Siwabessy, Kampus Baru UI Depok 16425 \\ E-mail:muhammadfaris1803@gmail.com
}

\begin{abstract}
Abstrak
Komposter merupakan alat untuk menampung kompos. Kompos sangat dibutuhkan oleh masyarakat khususnya yang gemar bercocok tanam. Dengan adanya alat monitoring komposter ini memudahkan masyarakat untuk mengecek suhu dan kelembapan dari kompos. Data suhu dan kelembapan dari kompos dikirimkan dari bagian pengirim ke bagian penerima menggunakan sebuah antena mikrostrip dengan bentuk patch serangga. Antena mikrostrip patch serangga bekerja pada frekuensi 2,4 GHz. Antena mikrostrip patch serangga merupakan pengembangan dari patch rectangular, sehingga dalam perhitungannya menggunakan rumus dasar antena patch rectangular. Perancangan dan simulasi antena dilakukan menggunakan software CST Studio Suite 2018. Simulasi dilakukan dengan melakuakn percobaan mengubah dimensi antena sehingga didapatkan hasil parameter yang terbaik. Parameter antena yang diukur adalah Voltage Standing Wave Ratio (VSWR), return loss, gain, dan pola radiasi. Hasil pengukuran parameter antena yang diperoleh yaitu VSWR sebesar 1,0772, return loss sebesar $28,5954 \mathrm{~dB}$, gain sebesar 4,249 dB, dan pola radiasi bidirectional.
\end{abstract}

Kata kunci : Antena, Gain, Mikrostrip patch serangga, Pola radiasi, Return loss, VSWR

\begin{abstract}
Composter is a tool for collecting compost. People really need compost, especially those who like to grow crops. With this composter monitoring tool, it makes it easier for people to check the temperature and humidity of the compost. Temperature and humidity from the compost are transmitted from the transmitter to the receiver using microstrip antenna with insect patch microstrip antenna. The insect patch microstrip antenna operates at a frequency of $2.4 \mathrm{GHz}$. This antenna is an extension of the rectangular patch, so the calculation uses the basic rectangular patch antenna formula. Antenna simulation was carried out using CST Studio Suite 2018. The measurement results of the antenna parameters obtained were VSWR of 1.0772, return loss of $-28.5954 \mathrm{~dB}$, gain of $4.249 \mathrm{~dB}$, and bidirectional radiation pattern.
\end{abstract}

Keywords : Antenna, Gain, Insect patch microstrip, Radiation pattern, Return loss, VSWR

\section{Pendahuluan}

Salah satu isu lingkungan pada era globalisasi saat ini yaitu sampah. Dalam kehidupan sehari-hari sampah banyak ditemukan di lingkungan sekitar. Setiap hari sampah selalu bertambah, dengan seiring berjalannya waktu sampah akan semakin menumpuk, maka dari itu salah satu cara untuk mengurangi jumlah sampah adalah mengelola sampah tersebut, salah satu caranya adalah membuat kompos menggunakan sampah organik. Sampah organik yang digunakan sebagai bahan dasar pembuatan kompos yaitu daun-daun kering, kulit buah, makanan sisa yang basi, buah busuk, dan gabah kering.

Proses pengomposan berlangsung selama kurang lebih dua pekan dengan dibantu cairan decomposer (EM4) untuk mempercepat proses penguraian sampah. Pada saat proses pengomposan, data yang diambil adalah suhu dan kelembaban kompos. Suhu optimum pengomposan berkisar antara $35-45^{\circ} \mathrm{C}$. 
Pengiriman data suhu dan kelembapan memanfaatkan antena mikrostrip sebagai antena pemancar. Antena mikrostrip dengan bentuk patch serangga di bagian pengirim digunakan untuk memancarkan sinyal elektromagnetik dengan frekuensi kerja yang digunakan 2,4 GHz.

\section{Metode Penelitian}

Antena mikrostrip pertama kali diperkenalkan pada tahun 1950, dan perkembangan terhadap teknologi ini mulai serius dilakukan pada tahun 1970. Melalui beberapa dekade penelitiannya, diketahui bahwa kemampuan beroperasi antena mikrostrip diatur terutama oleh bentuk geometri dan elemen peradiasi (patch) dan karakteristik material substrat yang digunakan. Oleh karena itu dimungkinkan dengan manipulasi yang tepat terhadap substrat, seperti penggunaan struktur EBG, akan memperbaiki karakteristik antena mikrostrip [1].

Untuk mengetahui kinerja dari antena, maka perlu diketahui berbagai nilai parameter antena. Karakteristik yang sangat penting untuk mengetahui kinerja suatu antena yaitu Voltage Standing Wave Ratio (VSWR), return loss, bandwidth, pola radiasi dan gain.

VSWR adalah tingkat ketidaksesuaian antara beban dan saluran transmisi pada antena, VSWR merupakan perbandingan antara amplitudo gelombang berdiri maksimum dengan minimum [3]. Perbandingan antara tegangan yang direfleksikan dengan tegangan yang dikirimkan disebut sebagai koefisien refleksi tegangan $(\Gamma)$ ditunjukan dengan Persamaan (1) [2].

$$
S=\frac{1+|\Gamma|}{1-|\Gamma|}
$$

Kondisi yang paling baik adalah ketika VSWR bernilai $1(\mathrm{~S}=1)$ yang berarti tidak ada refleksi ketika saluran dalam keadaan matching sempurna.

Return loss menunjukkan koefisien refleksi dalam bentuk logaritmik yang menunjukkan daya yang hilang karena antena dan saluran transmisi tidak matching. Ppersamaan untuk menghitung return loss ditunjukkan pada Persamaan (2) dan (3) [4].

$$
\begin{array}{r}
\text { Return loss }=20 \log |\Gamma| \\
\Gamma=\frac{V S W R-1}{V S W R+1}
\end{array}
$$

Dalam penelitian ini dilakukan beberapa tahapan penelitian untuk memperoleh desain dan dimensi antena mikrostrip patch serangga. Tahap awal adalah menetukan spesifikasi antena seperti diperlihatkan pada Tabel 1.
Tabel 1. Spesifikasi antena

\begin{tabular}{lc}
\hline \multicolumn{1}{c}{ Spesifikasi Antena } & Nilai \\
\hline Konstanta dielektrik relatif & 4,4 \\
Ketebalan substrat & $1,6 \mathrm{~mm}$ \\
Ketebalan konduktor & $0,1 \mathrm{~mm}$ \\
Impedansi bahan saluran & $50 \Omega$ \\
Frekuensi Kerja & $2,4 \mathrm{GHz}$ \\
Return Loss & $\leq-10 \mathrm{~dB}$ \\
VSWR & 1 atau $\leq 1,5$ \\
Gain & $>3 \mathrm{~dB}$ \\
Pola radiasi & Bidirectional \\
\hline
\end{tabular}

Setelah ditentukan spesifikasi dan parameter antena selanjutnya dilakukan perhitungan dimensi antena mikrostrip patch serangga, hasil perhitungan dimensi antena akan diterapkan pada software CST 2018. Setelah itu melakukan optimasi antena untuk mendapatkan parameter antena sesuai spesifikasi.

\subsection{Perancangan Antena}

Perhitungan panjang gelombang pada ruang bebas ditunjukkan pada Persamaan (4).

$$
\lambda_{0}=\frac{c}{f}
$$

Dimana :

$\lambda_{0}=$ Panjang gelombang $(\mathrm{mm})$

$\mathrm{c}=$ Kecepatan cahaya $\left(3 \times 10^{8} \mathrm{~m} / \mathrm{s}\right)$

$f=$ Frekuensi kerja $(\mathrm{GHz})$

Antena mikrostrip patch serangga merupakan pengembangan dari patch rectangular, berikut perhitungan panjang patch dan lebar patch. Panjang patch rectangular :

$$
\begin{gathered}
\varepsilon_{\mathrm{eff}}=\frac{\varepsilon r+1}{2}+\frac{\varepsilon r-1}{2}\left(\frac{1}{\sqrt{1+12(h / w)}}\right) \\
L_{e f f}=\frac{c}{2 f r \sqrt{\varepsilon_{e f f}}} \\
\Delta \mathrm{L}=0,412 \mathrm{~h} \frac{(\varepsilon e f f+0,3)\left(\frac{w}{h}+0,264\right)}{(\varepsilon e f f-0,258)\left(\frac{w}{h}+0,8\right)} \\
\mathrm{L}=L_{e f f}-2 \Delta L
\end{gathered}
$$

Lebar patch rectangular :

$$
\mathrm{W}=\frac{c}{2 f r} \sqrt{\frac{2}{\varepsilon_{r}+1}}
$$


Dimana :

$$
\begin{array}{ll}
\mathrm{L} & =\text { panjang patch }(\mathrm{mm}) \\
\varepsilon_{\mathrm{eff}} & =\text { konstanta dielektrik efektif } \\
\mathrm{h} & =\text { ketebalan substrat }(1.6 \mathrm{~mm}) \\
\Delta \mathrm{L} & =\text { panjang celah }(\mathrm{mm}) \\
\mathrm{W} & =\text { lebar patch }(\mathrm{mm}) \\
\varepsilon_{\mathrm{r}} & =\text { konstanta dielektrik }(4,4)
\end{array}
$$

Dari perhitungan panjang dan lebar patch data dibuat desain patch serangga dengan perhitungan sebagai berikut :

$$
\begin{aligned}
A x & =\frac{1}{2} L \\
A y & =\frac{1}{4} L \\
W x & =\frac{3}{16} W
\end{aligned}
$$

Untuk menentukan saluran pencatu antena mikrostrip $50 \Omega$, Panjang dan lebar saluran transmisi, serta lebar saluran transmisi yaitu

$$
\begin{array}{r}
Z_{L}=50 \Omega \\
Z_{0}=2 \times Z_{L} \\
\mathrm{~L}_{0}=\frac{\lambda 0}{4} \\
\mathrm{WZ}_{0}=\frac{377}{\sqrt{\varepsilon r}}\left(\frac{\mathrm{h}}{\mathrm{Z}_{0}}\right)
\end{array}
$$

Dimana :

$$
\mathrm{L}_{0} \quad=\text { Panjang saluran transmisi }(\mathrm{mm})
$$$$
\mathrm{WZ}_{0}=\text { Lebar saluran transmisi }(\mathrm{mm})
$$

Menentukan Panjang (Lg) dan Lebar (Wg) Substrat menggunakan persamaan berikut.

$$
\begin{array}{r}
L_{g}=6(W x)+L \\
W_{g}=6(W x)+W
\end{array}
$$

Setelah melakukan perhitungan matematis didapatkan desain antena mikrostrip patch serangga yang ditunjukkan pada Gambar 1.

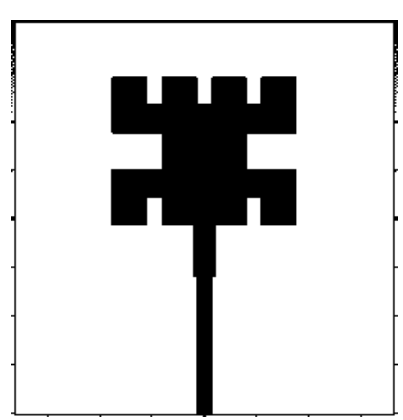

Gambar 1. Desain antena mikrostrip patch serangga

\section{Hasil dan Pembahasan}

Parameter antena yang diuji adalah VSWR, return loss, gain dan pola radiasi menggunakan CST 2018. Data hasil simulasi VSWR ditunjukkan pada Gambar 2.

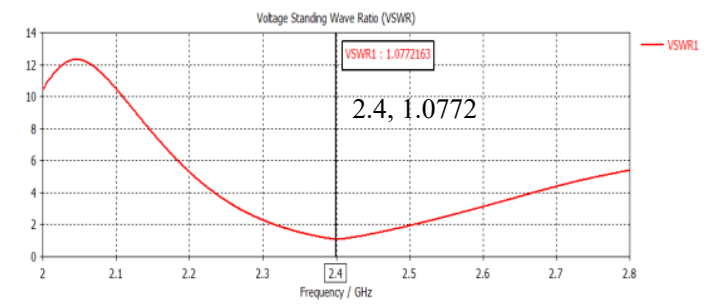

Gambar 2. Hasil simulasi VSWR antena mikrostrip patch serangga

Gambar 2 memperlihatkan hasil simulasi VSWR menggunakan CST 2018 pada frekuensi 2,4 GHz sebesar 1,0772 yang mana nilai tersebut sudah memenuhi spesifikasi yang diinginkan yaitu VSWR $\leq 1,5$. Data hasil simulasi return loss ditunjukkan pada Gambar 3.

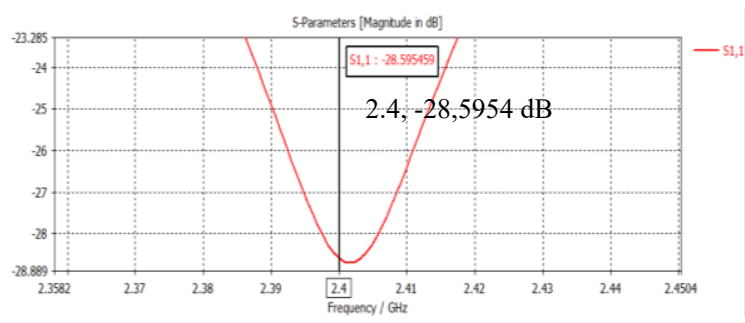

Gambar 3. Hasil simulasi return loss antena mikrostrip patch serangga

Gambar 3 memperlihatkan hasil simulasi return loss menggunakan CST 2018 pada frekuensi 2,4 GHz sebesar $-28,5954 \mathrm{~dB}$ yang mana nilai tersebut sudah memenuhi spesifikasi yang diinginkan yaitu $\leq-10$ dB. Gambar 4 memperlihatkan hasil simulasi gain menggunakan CST 2018 pada frekuensi 2,4 GHz sebesar 4,249 dB yang mana nilai tersebut sudah memenuhi spesifikasi yang diinginkan yaitu $>3 \mathrm{~dB}$.

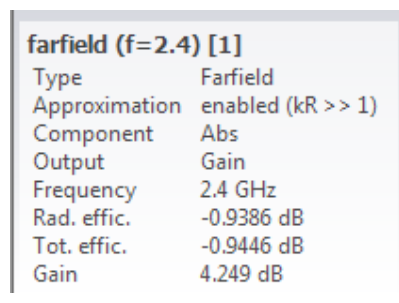

Gambar 4. Hasil simulasi gain antena mikrostrip patch serangga 
Gambar 5 memperlihatkan hasil simulasi pola radiasi menggunakan CST 2018 pada frekuensi 2,4 $\mathrm{GHz}$ yaitu berupa bidirectional sesuai dengan spesifikasi yang diinginkan.
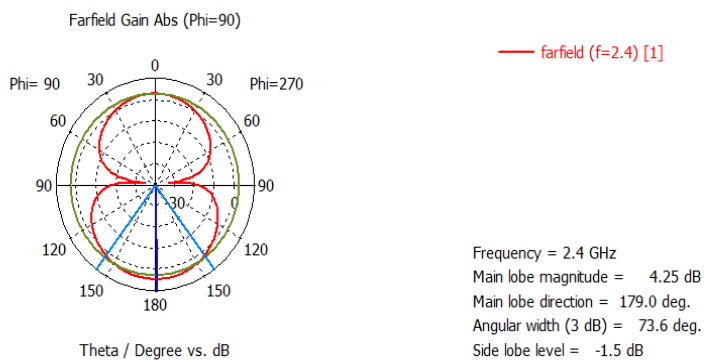

Gambar 5. Hasil simulasi pola radiasi antena mikrostrip patch serangga

Dari hasil simulasi, nilai VSWR, return loss, gain, dan pola radiasi yang didapatkan ditunjukkan pada Tabel 2 sebagai berikut :

Tabel 2 Hasil simulasi antena mikrostrip patch serangga

\begin{tabular}{cc}
\hline Parameter & Simulasi \\
\hline VSWR & 1,0772 \\
Return Loss & $-28,5954 \mathrm{~dB}$ \\
Gain & $4,249 \mathrm{~dB}$ \\
Pola Radiasi & Bidirectional \\
\hline
\end{tabular}

Berdasarkan hasil simulasi antena mikrostrip patch serangga untuk parameter VSWR, return loss, gain, dan pola radiasi didapatkan nilai simulasi yang sesuai dengan spesifikasi yang diinginkan. Dalam prosesnya, penulis melakukan 10 kali optimasi dengan mengubah-ubah dimensi antena yang dirancang dari perhitungan aslinya. Dimensi lebar patch memiliki pengaruh yang paling besar dalam mendapatkan nilai parameter VSWR dan return loss. Sedangkan dimensi bagian ground memiliki pengaruh yang paling besar dalam mendapatkan nilai parameter gain dan pola radiasi.

\section{Kesimpulan}

Perancangan antena mikrostrip patch serangga pada frekuensi 2,4 GHz dilakukan menggunakan software CST Studio Suite 2018. Optimasi antena dilakukan dengan mengubah-ubah dimensi lebar dan panjang patch antena. Perubahan terhadap lebar patch paling berpengaruh dalam mendapatkan VSWR dan return loss sesuai dengan spesifikasi yang diinginkan. Perubahan terhadap dimensi dan bentuk ground paling berpengaruh dalam mendapatkan gain dan pola radiasi sesuai dengan spesifikasi yang diinginkan.

\section{Daftar Acuan}

[1] Zulkifli, F. Yuli, Studi tentang antena microstrip dengan defected ground structure (DGS), Disertasi, Universitas Indonesia, 2008.

[2] B. L. Ooi, X. D. Xu, I. Ang, Triple-band Slot Antenna with Spiral EBG Feed, IEEE International Workshop on Antenna Technology, 2005.

[3] M, Fahrazal, Rancang Bangun Antena Mikrostrip Triple-Band Linier Array 4 Elemen untuk Aplikasi WiMax, Tugas Akhir, Universitas Indonesia, 2011.

[4] P. Akila, P. Akshaya, L. Aparna, J.M.S. Mol. Design and Analysis of Mikrostrip Patch Antenna Using Alumina and Paper Substrate for WiFi Application, International Research Journal of Engineering and Technology (IRJET), 2018 